\title{
A survey of Culicidae (Insecta Diptera) in some habitats in Souk-Ahras province (Northeast Algeria)
}

\author{
Nour-El Houda Hafsi ${ }^{1,2,3}$, Kaouther Hamaidia ${ }^{2,3^{*}}$, Choukri Barour ${ }^{2}$ \& Noureddine Soltani ${ }^{3}$ \\ ${ }^{1}$ Laboratory Sciences and Technical Water and Environment, Mohamed Cherif Messaadia University, Souk-Ahras, \\ Algeria \\ ${ }^{2}$ Department of Biology, Faculty of Nature and Life Sciences, Mohamed Cherif Messaadia University, Souk-Ahras, \\ Algeria \\ ${ }^{3}$ Laboratory of Applied Animal Biology, Faculty of Sciences, Department of Biology, Badji Mokhtar University of \\ Annaba, Annaba, Algeria \\ "Corresponding author, e-mail: k.hemaidia@univ-soukahras.dz
}

\begin{abstract}
A survey of immature Culicidae was conducted in diverse habitats of Souk-Ahras province (Northeast Algeria) between December 2018 and November 2019. Altogether, 12,861 specimens were collected and identified. Nineteen species of mosquitoes, belonging to two main subfamilies viz. Culicinae (accounts for $84.21 \%$ ) and Anophelinae (as $15.79 \%$ ), under 5 genera (Culex, Culiseta, Anopheles, Aedes and Uranotaenia). Among identified species, six were mentioned for the first time in the province of Souk-Ahras. The predominant species of the total mosquito fauna was $C x$. pipiens L. with an abundance rate of $69.63 \%$. Two habitats were characterized by the highest prevalence of 11 species, Taoura (with $1 \mathrm{spp}$. Anophelinae, $10 \mathrm{spp}$. Culicinae) and Sedrata (with $11 \mathrm{spp}$. of Culicinae). However, Souk-Ahras site contained the largest abundance (41.20 $\%$ ) belonging to 6 species. In addition, the spatial distribution of mosquitoes according to climatic factors (temperature, rainfall, humidity) was discussed. Data supported by some ecological indices of composition and structure revealed that the diversity level in Souk-Ahras province was between medium and very low compared to a scale varied between 0 and 1 (global Simpson index 0.50). The most diversified site in species was Taoura with the highest Shannon index value (2.11). Since vectors occurrence is constantly changing, it will be suggested that mosquito control should be intensified within other potential breeding sites in northeastern Algeria.
\end{abstract}

KEY WORDS Biodiversity; Climate; Distribution; Mosquito; Systematic.

Received 31.05.2020; accepted 10.12.2020; published online 25.01.2021

\section{INTRODUCTION}

Due to their epidemiological impacts in viral infections, several mosquito species are among the world's most major arboviral vectors (Tandina et al., 2018; Jones et al., 2020), such as Chikungunya (Prudhomme et al., 2019) and Zika (Kauffman \& Kramer, 2017). Understanding ecology, trophic preferences, and spatiotemporal distribution of these insects seems critical to implementing effective control programs. Because they are confined in water, it is more practical to control the mosquito's larvae with different ecofriendly insecticides like insect growth disruptors (Hamaidia K. \& Soltani 2014; Hamaidia K. et al., 2018; Hamaidia K. \& Soltani, 2019) or biopesticides (Dris et al., 2017a, 2017b; Djeghader et al., 2018; Bouzidi et al., 2020). 
In addition to the influence of spatio-temporal patterns on the presence of species and their larval development, altitude also plays an important role (Zimmerman, 2019). Environmental changes, trade, and tourism caused several mosquito-borne disease outbreaks which required strengthening vector management programs (Karungu et al., 2019). In the same region, climate change could cause fluctuations in species composition leading changes in dynamics transmission of mosquito-borne diseases (Afrane et al., 2012). There are positive correlations between rainfall and annual abundances in Culex pipiens and Ochlerotatus detritus (Roiz et al., 2014), while the presence of $\mathrm{Cx}$. quinquefasciatus relies on humidity (Asigau \& Parker, 2018). Temperature and rainfall were highly correlated with the abundance of mosquitoes as well (Simon-Oke \& Olofintoye, 2015; Hamaidia K. et al., 2016). A series of predictions between climate conditions, local vector dynamics and spatiotemporal dynamics of dengue has been reported (Li et al., 2019). Aedes albopictus abundance was highest in forest edge habitats, while Culex mosquitoes were found in human settlements (Brown et al., 2018). Outside of climatic factors, house age was found to be coherently associated with Ae. aegypti abundance; older houses had more mosquito eggs (Walker et al., 2011). Also, land cover influenced mosquito distribution, as $C x$. tarsalis and Ae. vexans were positively correlated with grass/hay and wetlands respectively (Chuang et al., 2011). However, biodiversity analysis indicated that species diversity in rural, urban and uninhabited areas was similar (Khoobdel et al., 2019). New progress requires as much attention to mosquito ecology as to their molecular biology (Godfray, 2013).

Climate change has become a top threat to biodiversity from genes over species to biome level (Sintayehu, 2018). Since aquatic landscapes are particularly vulnerable (Pletterbauer et al., 2018), it is predicted that climate change will affect the mosquitoes' distribution (Reinhold et al., 2018), and consequently will impact vector-borne diseases and health (Fouque \& Reeder, 2019; Pathak et al., 2019).

Although several studies have been carried out over the past two decades on the biodiversity of mosquito-fauna in Algeria (Messai et al., 2010; Bouabida et al., 2012; Lounaci et al., 2014; Benhissen et al., 2014; Merabti et al., 2017), there is always a lack in our knowledge of the culicidian fauna in Souk-Ahras province. Only three surveys were accomplished (Hamaidia K. et al., 2016; Benmalek et al., 2018; Hamaidia H. \& Bershi, 2018). In addition, some vector species have been reported in Algeria (Larfi et al., 2014; Benallal et al., 2019).

Therefore, the present study aims to update the inventoried list of Culicidae family in five habitats in Souk-Ahras region (Northeast Algeria) and provides insights into its composition and highlights, by several ecological indices, some of climate variables (temperature, rainfall and humidity) involved in its fluctuation. Data obtained permit us to enhance sustained mosquito control and management strategies.

\section{MATERIAL AND METHODS}

\section{Study area}

Souk-Ahras province, located in the far Northeast Algeria (Fig. 1), is characterized by a multitude of landscapes. The climatic conditions characterizing this region were predominantly distinguished by a sub-humid climate (warm summer and cold winter), with average annual temperature between $5.5^{\circ} \mathrm{C}$ and $26.8^{\circ} \mathrm{C}$ and an annual rainfall of 0 to $330.3 \mathrm{~mm}$. The study area comprised five sampling sites. In total, 19 immature mosquitos' biotopes have been selected on the basis of their accessibility and the presence of mosquito immature instars; Souk-Ahras, Zarouria, Mechroha, Sedrata and Taoura communes at an altitude of $653,743,769$, $811,839 \mathrm{~m}$, respectively. This mountainous region is known for its agricultural landscapes, its dense forest cover and several rivers flowing through it.

The larval breeding sites of Sedrata, 36 $7^{\circ} 44^{\prime \prime} \mathrm{N}$ 7³1'41'"E, were located in Oued Krab containing aquatic vegetation, near to human habitations and dumps, placed 6-8 $\mathrm{km}$ from a wastewater treatment plant. The site of Taoura, 36 10 '3"N 82'25' E, is a permanent lake near a forest cover. Breeding sites of Souk-Ahras commune, 36¹7'11'N 757'4'E, were situated in Oued Medjerda that flows through

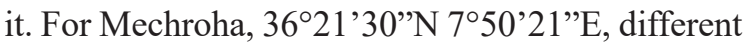
habitats were prospected: rural (less profound with dense vegetation) and artificial larval habitats (without vegetation and clean water). Zarouria, $36^{\circ} 13$ ' $42^{\prime}$ N $7^{\circ} 57^{\prime} 22^{\prime \prime} \mathrm{E}$, habitats were located in Oued Hamam Tessa (poor vegetation, rural zone, pollution, agricultural lands). 


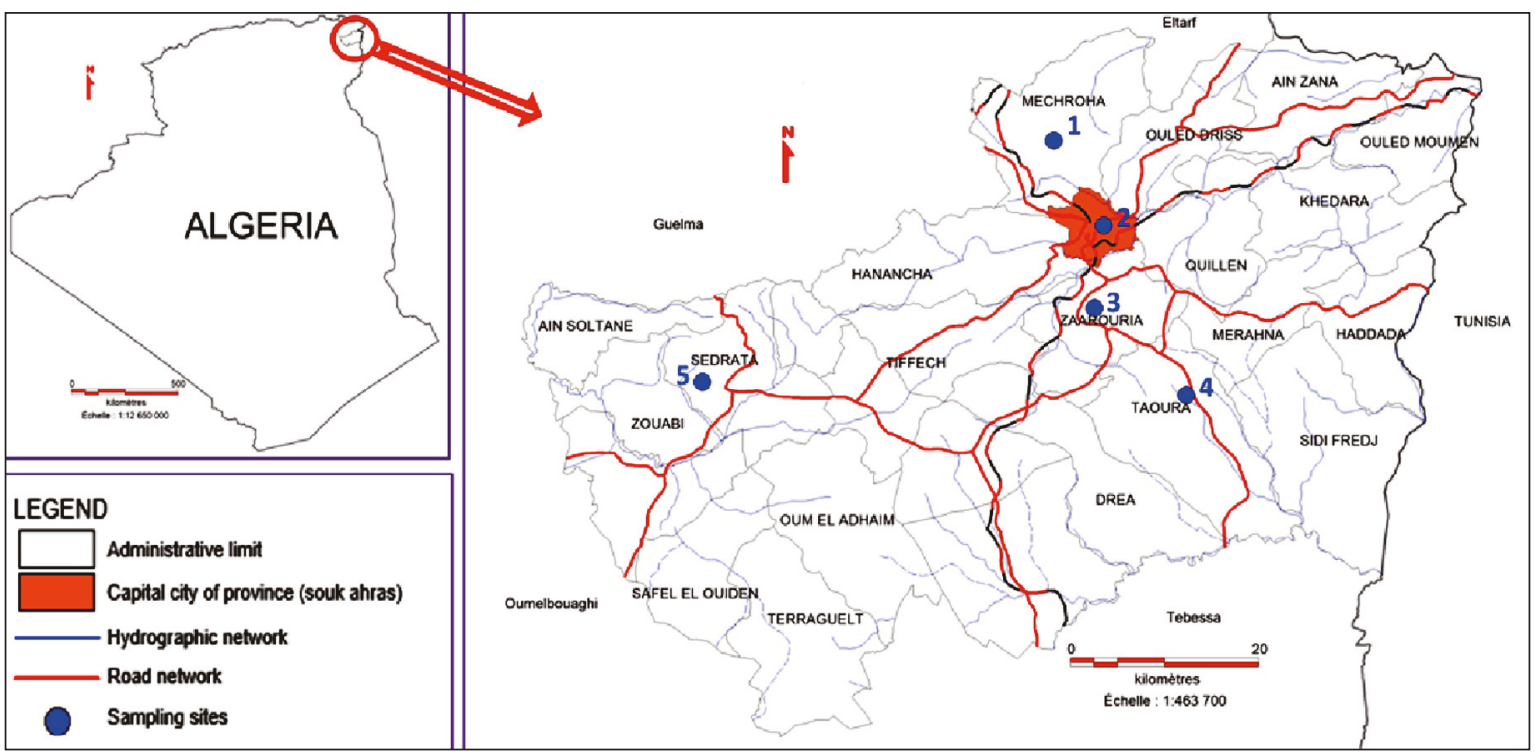

Figure 1. Sampling sites of immature mosquitoes in Souk-Ahras province (1: Mechroha; 2: Souk-Ahras; 3: Zarouria; 4: Taoura and 5: Sedrata).

\section{Mosquito sampling, rearing and identification}

Over 12 months (from December 2018 to November 2019) immature mosquitoes from each larval breeding site of the study region were sampled bi-monthly using "dipping" technique with a metal dipper $(300 \mathrm{ml})$. Ten dips were taken from each. Samples were brought back alive to the laboratory of Sciences and Technical Water and Environment, Mohamed Cherif Messaadia University (SoukAhras, Algeria). Larvae were sorted by station and date and stored in labeled tubes containing $70 \%$ ethanol until their identification. Rearing of collected pupae was carried out in cubic cages covered with net at $25 \pm 2^{\circ} \mathrm{C}$ until adult emergence. Culicidae larvae and laboratory-reared adults were frozen at $-18^{\circ} \mathrm{C}$ for $20 \mathrm{~min}$. External morphology-based identification to species of specimens was made according to the software of Brunhes et al. (1999).

\section{Data analysis}

To express the Culicidae fauna diversity in Souk-Ahras province, different statistical tools, graphs and indices were used in the present study to assess the alpha diversity between five contrasting habitats. The species richness $(S)$ and the number of individuals (Abundance A) of each species present were recorded in the study sites. All analy- ses were performed using $\mathrm{R}$, version 3.6.1 (R Core Team 2019; Ihaka \& Gentleman, 1996) for MacOS (http://cran.r-project.org). Graphs (Barplots, Corrplots, Cleveland plots, Pie Donut plots and two y scales plots) and ecological indices (ShannonWeaver diversity index $H^{\prime}$, Simpson's index $D$, Piélou's evenness index $J^{\prime}$ and Sørensen similarity index) were obtained by using the following $\mathrm{R}$ packages : 'ggplot2' (Wickham, 2016), 'ggcorrplot' (Kassambara, 2019) , 'webr' (Moon 2020) and 'EcoIndR' (Guisande et al., 2017). Furthermore, to investigate a possible association between species abundances and three measured climatic parameters (mean temperature, average rainfall and average humidity), we calculated Spearman's rank correlation with a significance level of $\alpha=0.05$ using 'Hmisc' R package (Harrell, 2020).

\section{RESULTS}

\section{Inventoried species}

Following our survey covering five simple sites in Souk-Ahras province, a total of 12,861 specimens of mosquitoes (Diptera Culicidae) were collected and identified (Table 1; Fig. 2). Data recorded 19 mosquito species belonging to 2 subfamilies Culicinae (84 \%) and Anophelinae (16\%), 
divided into 5 genera: Culex, Culiseta, Anopheles, Aedes and Uranotaenia (Fig. 3) as follows: Cx. pipiens (Linnaeus, 1758), Cx. hortensis (Ficalbi, 1889), Cx. theileri (Theobald, 1903), Cx. simpsoni (Theobald, 1905), Cx. antennatus (Becker, 1903), Cx. martini (Medschid, 1930), Cx. adairi (Kirkpatrick, 1926), Cx. territans (Walker, 1856), Cx. arbieeni (Salem, 1938), Cx. quinquefasciatus (Say, 1823), Cx. laticinctus (Edwards, 1913), Cs. morsitans (Theobald, 1901), Cs. annulata (Schrank,
1776), Cs. longiareolata (Macquart, 1828), An. labranchiae (Falleroni, 1926), An. claviger (Meigen, 1804), An. marteri (Senevet et Prannelle, 1927), Ae. flavescens (Mueller, 1764) and Ur. unguiculata (Edwards, 1913). The most dominant genus was Culex $(89.78 \%$ ) of the total inventoried fauna with 11 spp., with abundance of $C x$. pipiens (69.63\%). The other genera Culiseta, Aedes, Uranotaenia and Anopheles were the least prevalent (9.02\%, $0.27 \%, 0.19 \%$ and $0.73 \%$, respectively).

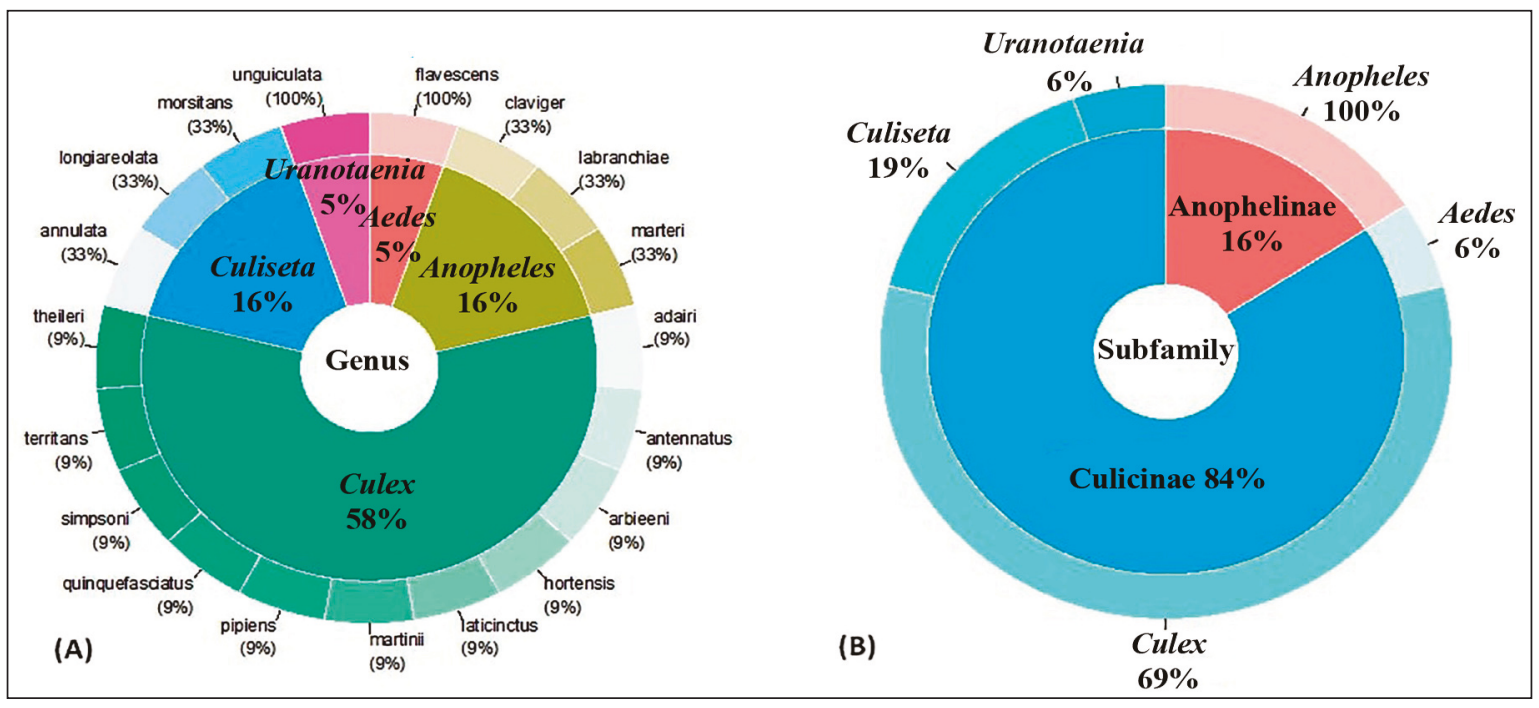

Figure 2. Ratios recorded between the different genera (A) and between the different subfamilies (B) of Culicidae fauna in Souk-Ahras province.

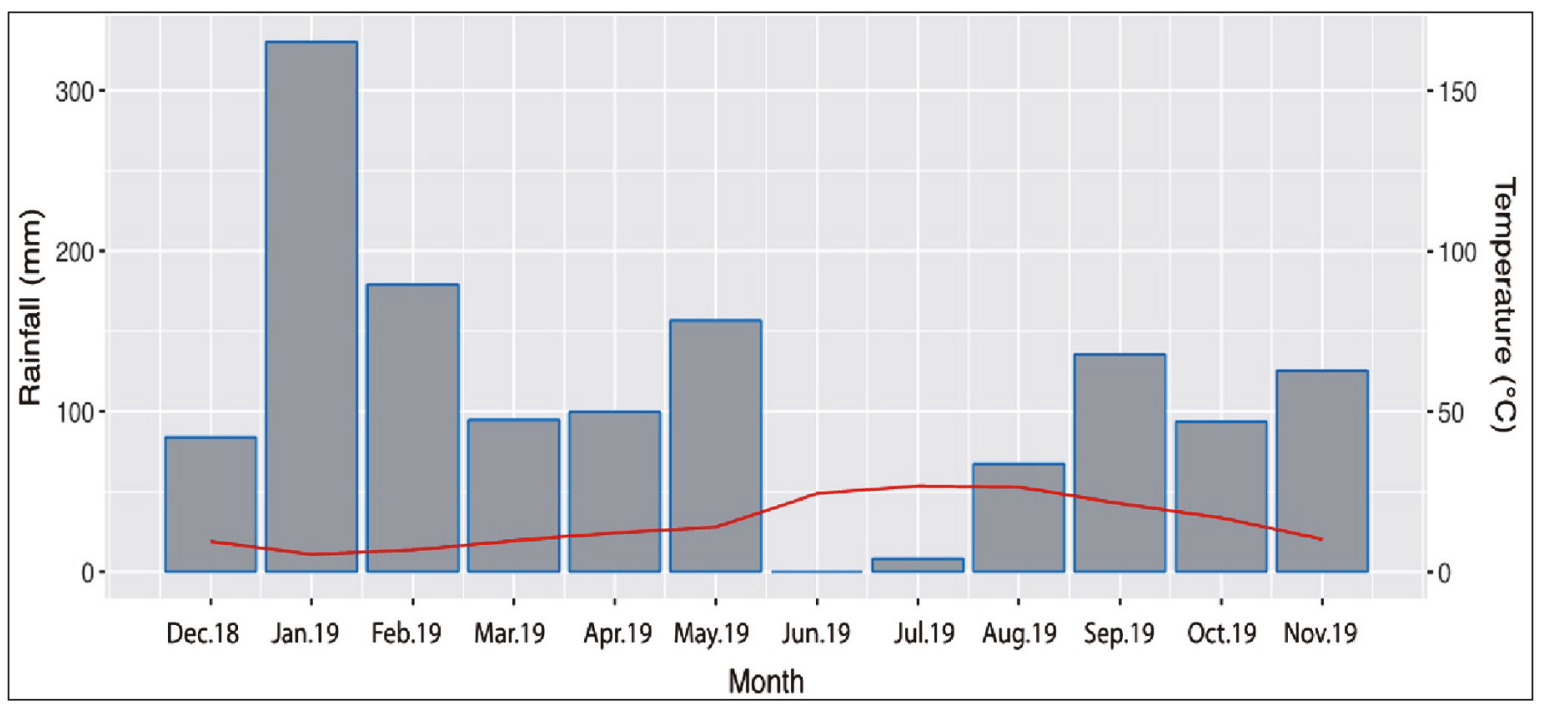

Figure 3. Monthly variation of rainfall ( $\mathrm{mm}$; barplot) and temperature $\left({ }^{\circ} \mathrm{C}\right.$; solid line) in Souk-Ahras province during the studied period (December 2018 to November 2019). 


\section{Seasonal fluctuation of abundances}

Three ecological factors (mean temperature, average rainfall and average humidity) were considered of all sites. During December 2018 to November 2019 period, the average maximum and minimum temperatures were $26.8^{\circ} \mathrm{C}$ and $5.5^{\circ} \mathrm{C}$ in July and January, respectively. As shown in Fig. 3, two wet periods were noted; between December 2018 and March

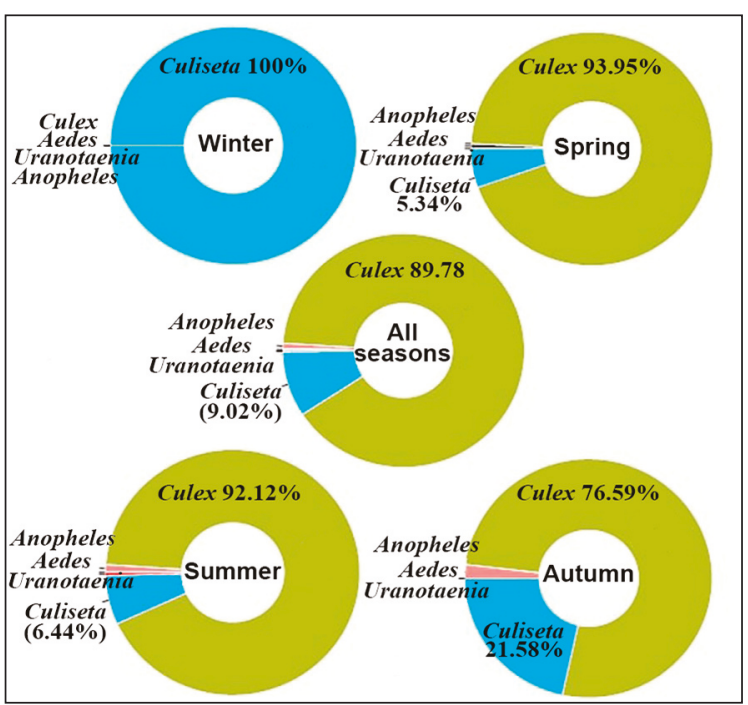

Figure 4. Seasonal genera composition of collected mosquitoes in Souk-Ahras province during December 2018 - November 2019 period.
2019, then from September to November, separated with a long dry season from May to September 2019.

The collected data revealed that the highest numbers of mosquitoes (overall abundances) were collected in summer $(6,042)$ and spring $(4,942$ specimens), while the lowest ones were found in both autumn (1,747 specimens) and winter (130 specimens). According to figure 4, the genus Culex predominated the following seasons: spring, summer and autumn with $93.95,92.12$ and $76.59 \%$ rates respectively. In contrast, winter season was dominated only by the Culiseta genus.

Variation in overall abundances (A) of mosquitoes depending to temperature is provided in figure 5. During cold rainy season, mosquito overall abundance was significantly reduced because of the destruction of some breeding sites by precipitations or the instability of others. Major fluctuations between the overall abundances of different taxa were observed in this study. Cs. longiareolata was collected from prospected habitats all over the year (four seasons). $C x$. pipiens and $C x$. theileri were found during spring, summer and autumn seasons because larval and adult populations have seasonal fluctuations and that overwintering females enter hibernacula in autumn and survived to emerge in the spring after complete hibernation (Simsek, 2004; Andreadis et al., 2010). For $C x$. hortensis, it was harvested only during two seasons (spring and summer). Dynamics of $C x$. hortensis populations followed a classic ther-

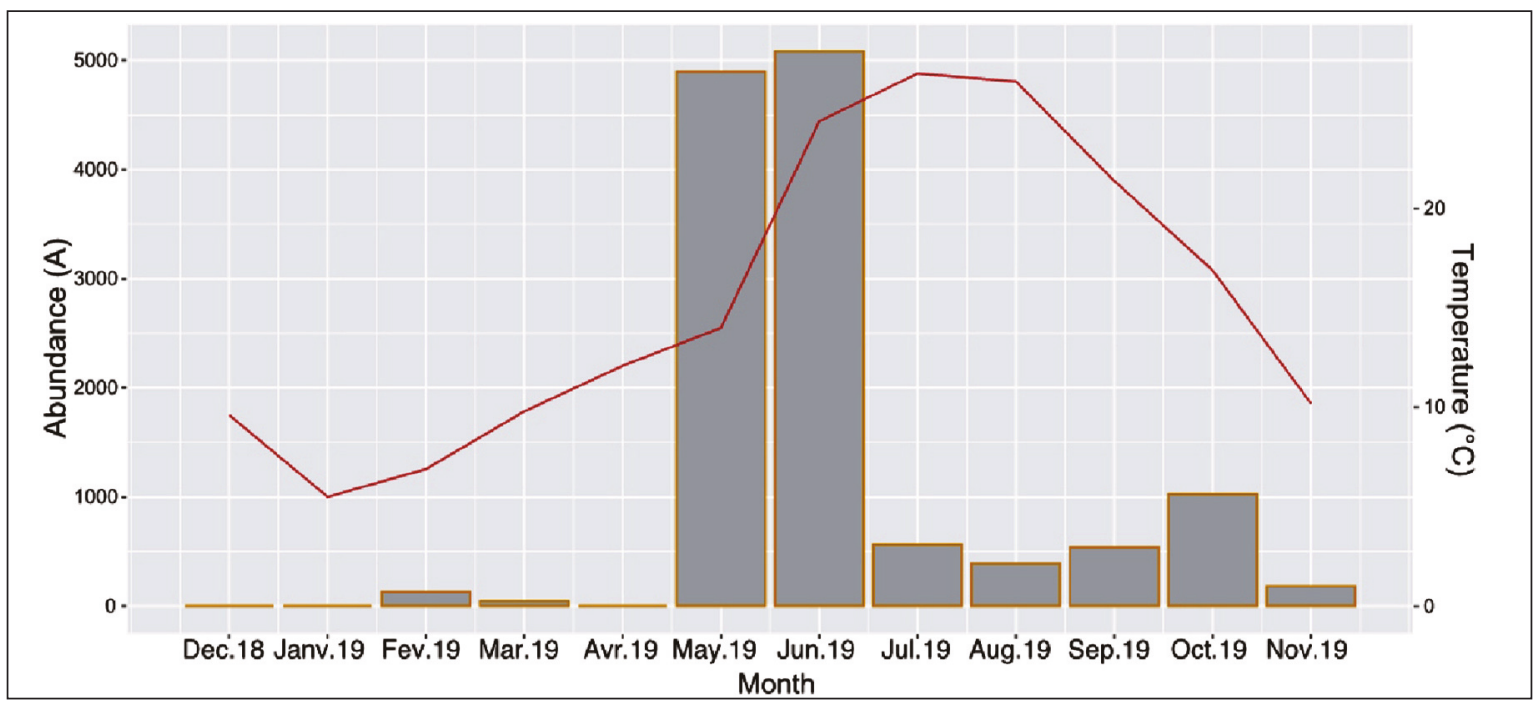

Figure 5. Monthly variations of mosquitoes overall abundances (barplot) in relation with mean temperature changes (solid line) in Souk-Ahras province during the studied period (December 2018 to November 2019). 
mophilic trend (Lounaci et al., 2016); three spring species (viz. $C x$. simpsoni, $C x$. antennatus and $C x$. territans) and one summer species (Cx. laticinctus) were found in our study sites. The statistical analyses revealed firstly, that temperature and rainfall were negatively correlated $(r=-0.68 ; p=0.015)$, while humidity had positive and negative correlations respectively with rainfall $(r=0.70 ; p=0.011)$ and temperature $(r=-0.84 ; p=0.007)$ (Fig. 6). These correlations could facilitate the explanation of the climatic changes in Souk-Ahras province. Secondly, we noticed also that the overall abundance of species was highly correlated with temperature $(r=0.73 ; p$ $=0.008)$ and relative humidity $(r=-0.69 ; p=0.010)$, but no significant correlation was found between overall abundances and rainfall $(p>0.05)$.

\section{Mosquito taxa and ecological indices}

In different ways the indices describe taxa rich- ness and the distribution of individuals among taxa. The greatest number of mosquitoes was collected from Souk-Ahras (5,299 specimens) although it only presents 6 species (Fig. 7). From a richness point of view (Figs. 7, 8), Taoura and Sedrata sampling sites presented the highest number of species $(\mathrm{S}=11)$. The highest Shannon's index value was recorded in Taoura $\left(\mathrm{H}^{\prime}=2.11\right)$, which indicated that it is the most diversified site in our study; while the lowest value was recorded in Zarouria $\left(\mathrm{H}^{\prime}=0.53\right)$ due its low richness $(\mathrm{S}=3)$. For the Pielou's evenness index, our results showed in general a relative medium equitability between the observed taxa in their habitats. Moreover, the higher value was obtained in Mechroha $\left(J^{\prime}=0.63\right)$. Despite the weak sample size in Zarouria site, it showed with Sedrata site similar values of this index, $\mathrm{J}^{\prime}=0.34$ and $\mathrm{J}^{\prime}=0.33$, respectively. With regard to the Simpson's index, it showed that the diversity of all our sites was slightly variable with medium diversity level $(\mathrm{D}=0.50)$.

\begin{tabular}{|l|c|c|c|c|c|c|}
\hline \multicolumn{1}{|c|}{ Species / habitats } & Souk-Ahras & Taoura & Sedrata & Mechroha & Zarouria & $\begin{array}{c}\text { Total / } \\
\text { Species }\end{array}$ \\
\hline Culex pipiens & 3,880 & 1,598 & 2,481 & 766 & 231 & 8,956 \\
\hline Culex theileri & 0 & 258 & 194 & 35 & 0 & 487 \\
\hline Culex simpsoni & 0 & 313 & 3 & 0 & 0 & 316 \\
\hline Culex hortensis & 469 & 380 & 12 & 10 & 0 & 871 \\
\hline Culex antennatus & 12 & 0 & 315 & 0 & 0 & 327 \\
\hline Culex martinii & 0 & 0 & 43 & 0 & 0 & 43 \\
\hline Culex adairi & 0 & 0 & 4 & 0 & 0 & 4 \\
\hline Culex territans & 54 & 15 & 0 & 242 & 0 & 311 \\
\hline Culex arbieeni & 1 & 58 & 0 & 0 & 0 & 59 \\
\hline Culex quinquefasciatus & 0 & 12 & 0 & 0 & 0 & 12 \\
\hline Culex laticinctus & 0 & 161 & 0 & 0 & 0 & 161 \\
\hline Culiseta morsitans & 0 & 0 & 7 & 0 & 0 & 7 \\
\hline Culiseta annulata & 0 & 13 & 5 & 0 & 0 & 18 \\
\hline Culiseta longiareolata & 883 & 6 & 0 & 239 & 7 & 1135 \\
\hline Aedes flavescens & 0 & 0 & 35 & 0 & 0 & 35 \\
\hline Uranotaenia unguiculata & 0 & 0 & 25 & 0 & 0 & 25 \\
\hline Anopheles marteri & 0 & 62 & 0 & 0 & 0 & 62 \\
\hline Anopheles claviger & 0 & 0 & 0 & 15 & 0 & 15 \\
\hline Anopheles labranchiae & 0,299 & 2,876 & 3,124 & 1,307 & 255 & $\mathbf{1 2 , 8 6 1}$ \\
\hline Total & & & 0 & 0 & 17 & 17 \\
\hline
\end{tabular}

Table 1. List of mosquito species collected from Souk-Ahras province and their abundances (December 2018 - November 2019). 
According to Sørensen similarity index values, the similarity in species between the five prospected sites was medium $(0.67>B>0.44)$. It was found that Souk-Ahras and Mechroha were the most similar habitats in species $(\mathrm{B}=0.67)$. Taoura presented the same rate of common species with both SoukAhras and Mechroha $(\mathrm{B}=0.59)$; while it presented less common species with Sedrata $(B=0.45)$.

\section{DISCUSSION}

Among the Culicidae family, two sub-families have particular medical interest: Anophelinae, with the most important genus, Anopheles; and Culicinae, mainly with Aedes and Culex. Adults of Anopheles and Culex spp. exhibited nocturnal or crepuscular biting activity but some species are diurnal (Aedes spp.) (Berenger \& Parola, 2017; Foster \& Walker, 2019). Also, it is important to consider indigenous species as potential vectors for emerging arboviruses (Prudhomme et al., 2019). Results from mosquito survey's studies carried out in different Algerian areas, in terms of recorded species, are summarized in Table 2.

The focus of this study was to describe the mosquito assemblages (species richness and abundance) in Souk-Ahras province. Nineteen mosquito species were identified, between which Culex species have been reported in all prospected breeding sites. It might be attributed to the investigation of many polluted breeding sites which could have provided favorable environment for the proliferation of Culex species (Farjana et al., 2015).

The densities of mosquitoes and their diversity at species- and population-level are seasonally dependent because of the abiotic factors such as temperature, rainfall and moisture influence (Reinhold et al., 2018). The egg hatching, larval and pupal development (Saari et al., 2019) and the life span of the adult's effective transmission capacity of parasites (Bogitsh et al., 2019) depended on the temperature. It was reported that mosquito species were spreading northwards as a consequence of climate warming (Tippelt et al., 2017). Thus, geographic distributions of previously tropical mosquito species may change (Waldock et al., 2013). Previously in Algeria, it has been reported infected cases with West Nile virus (Lafri et al., 2017; Larfi et al., 2019). Aedes albopictus, an invasive mosquito species responsible for transmission

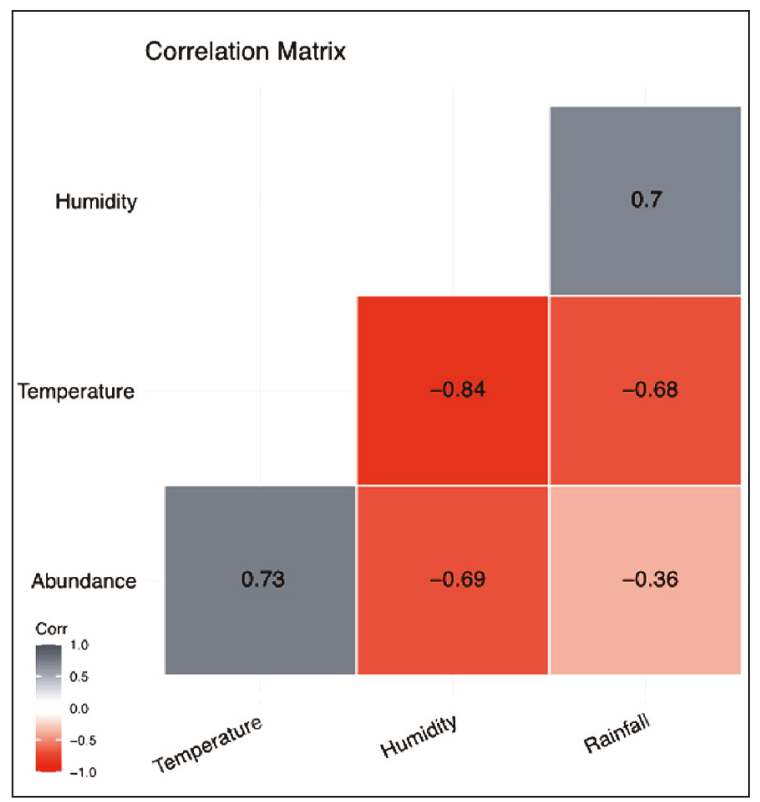

Figure 6. Graphical display of the correlation matrix using the 'corrplot' package of R; Spearman's rank correlations between three climatic variables (temperature, rainfall and humidity) and overall abundances of species $(n=12)$.

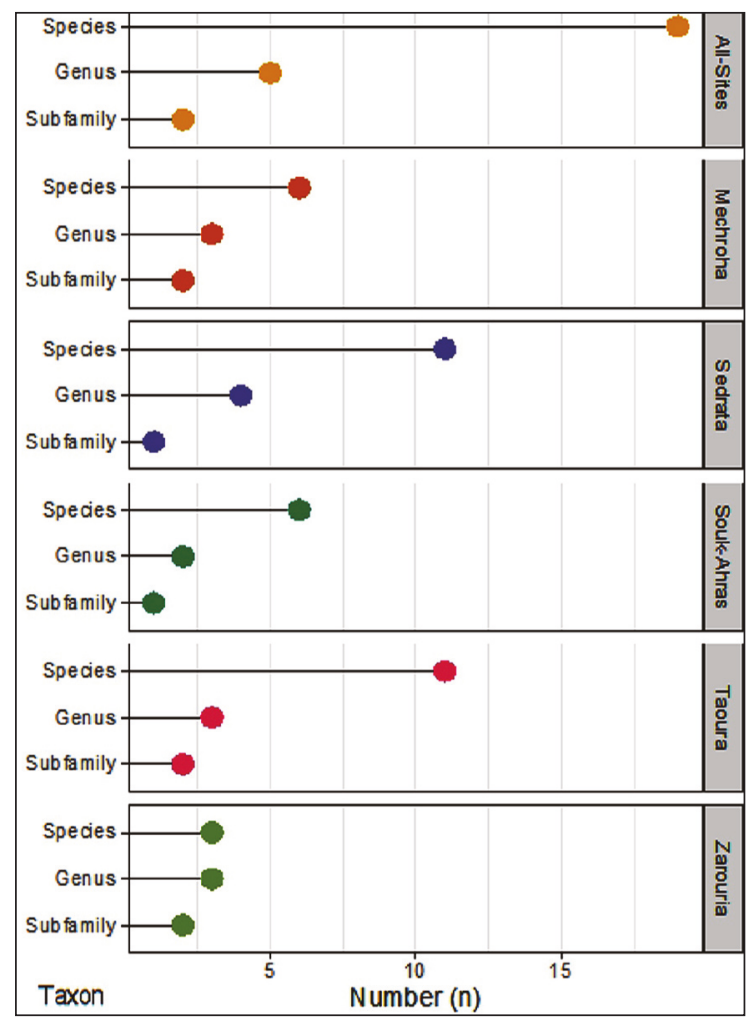

Figure 7. Taxa recorded within mosquitoes populations in different habitats from Souk-Ahras province the studied period (December 2018 to November 2019). 
of chikungunya virus, has been first recorded during July 2016 in Algiers (Benallal et al., 2019). Due to distinct ecological preferences between populations (Asha \& Aneesh, 2014), their response to climate fluctuations differed for survival. Mosquitoes adopt several forms of survival face of adverse conditions. Depending on the species, eggs or larvae can survive over winter and do not continue development (Saari et al., 2019). For example, the populations of mosquito inhabiting contrasted ecological areas used different aestivation strategies (Hidalgo et al., 2016).

During the past two decades, only three works focused on mosquitoes biodiversity in Souk-Ahras region (Hamaidia H. \& Bershi, 2018; Hamaidia K. et al., 2016; Benmalek et al., 2018) with 13 common species have been identified: $C x$. pipiens, $C x$. hortensis, $C x$. theileri, $C x$. quinquefasciatus, $C x$. arbieeni, Cx. simpsoni, Cx. antennatus, Cx. martini, Cx. laticinctus, Cs. morsitans, Cs. longiareolata, Cs. annulata and An. labranchiae.

The present results revealed a medium level of Culicidae fauna diversity in Souk-Ahras province because of dominance of $C x$. pipiens due to its high ecological and physiological plasticity (Amara Korba et al., 2016; Tabbabi et al., 2018). This species was the most reported in several Algerian surveys (Messai et al., 2010; Benhissen et al., 2014;
Hamaidia K. et al., 2016). Unlike larvae of Culex species, that breed profusely in polluted environments, Aedes and Anopheles mosquitoes prefer clean ground pools (Farjana et al., 2015) and unpolluted sites that contain sunny fresh water with slow current without raised vegetation (Tandina et al., 2018) respectively. Furthermore, urbanization is one of the drivers causing a significant depletion of the breeding sites of Anopheles species which decreases their density in favor of Culex species, better suited to this kind of lodgings (Tabbabi et al., 2017). Culiseta species were considered as mosquito fauna of the more humid and cold climate areas (Trájer \& Padisák, 2019).

Some mosquitoes were innately adapted to distinct ecological exigencies and associated with particular host species. Such relations need to be expected in field-based studies, because variability in climatic factors is the most important driver of mosquito species redistribution (Hertig, 2019; Messina et al., 2019). During our survey, 6 new species were recorded in Souk-Ahras province, viz. Cx. territans, Ae. flavescens, Ur. unguiculata, An. claviger, Cx. adairi and An. marteri.

All specimens of $C x$. territans were collected in early May from three sites (Souk-Ahras, Taoura and Mechroha at an altitude of 653,839 and $769 \mathrm{~m}$ re-

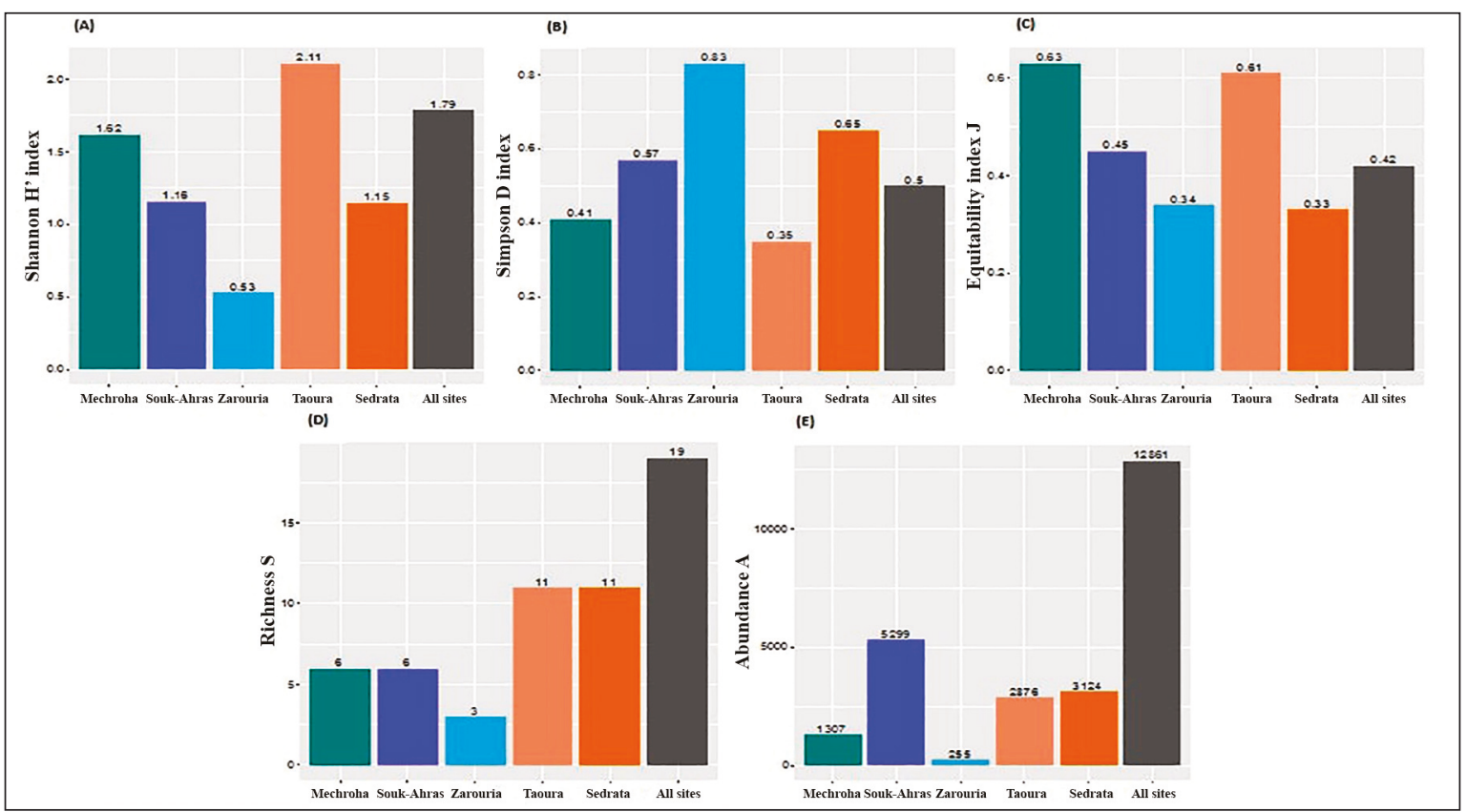

Figure 8. The ecological indices of composition and structure calculated for each sampling site in the Souk-Ahras province. 


\begin{tabular}{|c|c|c|c|}
\hline Region & Species/Genus & Species & Reference \\
\hline Mila & \begin{tabular}{l|} 
Culex \\
1 Culiseta \\
2 Anopheles \\
1 Uranotaenia \\
\end{tabular} & $\begin{array}{l}12 \text { spp. - Cx. pipiens, Cx. modestus, Cx. theileri, Cx. hortensis, Cx. an- } \\
\text { tennatus, Cx. laticinctus, Cx. deserticola, CX. sp, C. longiareolata, An. } \\
\text { labranchiae, An. pharoensis, U. unguiculata }\end{array}$ & $\begin{array}{l}\text { Messai } \\
\text { et al., } 2010\end{array}$ \\
\hline Tébessa & $\begin{array}{l}5 \text { Culex } \\
3 \text { Culiseta } \\
1 \text { Ochlerotatus }\end{array}$ & $\begin{array}{l}9 \text { spp. - Cx. pipiens, Cx. theileri, Cx. hortensis, Cx. perexiguus, Cx. } \\
\text { laticinctus, Oc. caspius, Cs. longiareolata, Cs. annulata, Cs. subochrea }\end{array}$ & $\begin{array}{l}\text { Bouabida } \\
\text { et al., } 2012\end{array}$ \\
\hline Reghaïa & $\begin{array}{l}8 \text { Culex } \\
1 \text { Aedes } \\
1 \text { Culiseta } \\
1 \text { Anopheles } \\
1 \text { Cranotaenia }\end{array}$ & $\begin{array}{l}12 \text { spp. - Cx. mimeticus, Cx. perexiguus, Cx. pipiens, Cx. theileri, Cx. } \\
\text { modestus, Cx. hortensis, Cx. impudicus, Cx. territans, Ae. caspius, Cs. } \\
\text { longiareolata, An.labranchiae, Uranotaenia unguiculata }\end{array}$ & $\begin{array}{l}\text { Lounaci } \\
\text { et al., } 2014\end{array}$ \\
\hline Biskra & $\begin{array}{l}7 \text { Culex } \\
2 \text { Aedes } \\
1 \text { Culiseta } \\
1 \text { Anopheles } \\
\end{array}$ & $\begin{array}{l}11 \text { spp. - Cx. pipiens, Cx. theileri, } C x . \text { deserticola, Cx. modestus, Cx. tor- } \\
\text { rentium, Cx. pusillus, Cx. antennatus, Cs. longiareolata, Ae. caspius, Ae. } \\
\text { vexans, An. multicolor }\end{array}$ & $\begin{array}{l}\text { Benhissen } \\
\text { et al., } 2014\end{array}$ \\
\hline $\begin{array}{l}15 \text { departments } \\
\text { in Algeria }\end{array}$ & 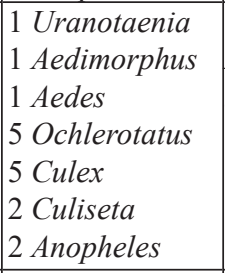 & $\begin{array}{l}17 \text { spp. - Aedes albopictus, Aedimorphus vexans, Anopheles labranchiae, } \\
\text { An. multicolor, Culex deserticola, Cx. hortensis, Cx. pipiens, Cx. terri- } \\
\text { tans, Cx. theileri, Culiseta litorea, C. longiareolata, Ochlerotatus coluzzii, } \\
\text { O. detritus, O. dorsalis, O. flavescens, O. geniculatus, Ur. unguiculata }\end{array}$ & $\begin{array}{l}\text { Larfi } \\
\text { et al., } 2014\end{array}$ \\
\hline Tizi-Ouzou & $\begin{array}{l}1 \text { Anopheles } \\
4 \text { Culex } \\
1 \text { Culiseta } \\
2 \text { Aedes } \\
\end{array}$ & $\begin{array}{l}8 \text { spp. - An. labranchiae, Cx. hortensis, Cx. impudicus, Cx. theileri, Cx. } \\
\text { perexiguus, Cs. longiareolata, Ae. caspius, Ae. vexans }\end{array}$ & $\begin{array}{l}\text { Lounaci } \\
\text { et al., } 2016\end{array}$ \\
\hline Souk-Ahras & \begin{tabular}{|l|}
7 Culex \\
3 Aedes \\
3 Culiseta \\
2 Anopheles \\
1 Orthopodomyia \\
\end{tabular} & $\begin{array}{l}16 \text { spp. - Cx. pipiens, Cx. theileri, Cx. modestus, Cx. simpsoni, Cx. quin- } \\
\text { quefasciatus, Cx. hortensis, Cx. arbieeni, Ae. punctur, Ae. quasirusticus, } \\
\text { Ae. pulcritarsis, Cs. longiareolata, Cs. fumipennis, Culiseta sp1, Or. pul- } \\
\text { cripalpis, An. algeriensis, An. labranchiae }\end{array}$ & $\begin{array}{l}\text { Hamaidia K. } \\
\text { et al., } 2016\end{array}$ \\
\hline $\begin{array}{l}\text { Souk-Ahras } \\
\text { (Taoura) }\end{array}$ & $\begin{array}{l}8 \text { Culex } \\
3 \text { Culiseta } \\
3 \text { Anopheles }\end{array}$ & $\begin{array}{l}14 \text { spp. - Cx. pipiens, Cx. theileri, Cx. laticinctus, Cx. antennatus, Cx. } \\
\text { hortensis, Cx. perexiguus, Cx. mimeticus, Cx. impudicus, Cs. longiareo- } \\
\text { lata, Cs. subochrea, Cs. annulata, An. labranchiae, An. petragnani, An. } \\
\text { rufipes broussesi }\end{array}$ & $\begin{array}{l}\text { Hamaidia H. } \\
\text { \& Bershi, } 2018\end{array}$ \\
\hline $\begin{array}{l}\text { Souk-Ahras } \\
\text { (Taoura) }\end{array}$ & $\begin{array}{l}12 \text { Culex } \\
3 \text { Culiseta } \\
2 \text { Anopheles } \\
1 \text { Aedes }\end{array}$ & $\begin{array}{l}18 \text { spp. - Cx. deserticola, Cx. univittatus, Cx. torrentium, Cx. pere- } \\
\text { gxiguus, Cx. impudicus, Cx. mimeticus, Cx. martini, Cx. pipiens, Cx. thei- } \\
\text { leri, Cx. brumpti, Cx. mauritanicus, Cx. modestus, Cs. morsitans, Cs. } \\
\text { subochrea, Cs. annulata, An. coustani, An. hyrcanus, Ae. pilatus }\end{array}$ & $\begin{array}{l}\text { Benmalek } \\
\text { et al., } 2018\end{array}$ \\
\hline
\end{tabular}

Table 2. Mosquito systematic inventories in different Algerian biotopes.

spectively) inhabited by frogs. Each mosquito species required a specific group of hosts for their blood feeding (Bingham et al., 2013). Females of $C x$. territans have a preference for amphibian bloodmeals. Therefore, larvae were temporally and spatially synchronized with these hosts. It was reported that the first larvae harvest of this species were collected on May (Bartlett-Healy et al., 2008). Larfi et al., (2014) noted the first record of Cx. territans in Algeria, at an altitude of $1,750 \mathrm{~m}$.
Aedes flavescens and Cx. adairi larvae were harvested both in Sedrata site near to human habitations. This breeding site was sunny and stagnant craters formed on the edge of Oued Krab after its overflow on May. This coincided with the decrease in rainfall and the gradual increase in temperature. Larvae of Ae. flavescens were frequently occurring in stagnant, temporary, sunny habitats and without trees and shrubs as holes and marshes around rivers with feeding preference on the mammals then birds and reptile 
(Moradi-Asl et al., 2019). Cx. adairi is thermophilic species with a restricted distribution (temporary rainpools) and shorter period of occurrence (April and May only) (Dimentman \& Margalitj, 1981).

As for Ur. unguiculata, larvae were collected in June at one locality situated in Oued Krab containing aquatic vegetation in Sedrata site only. This collection period is characterized by an increase in temperature without rainfall. This mosquito species is thermophilic and widespread throughout the Mediterranean (Kurucz et al., 2017; Tippelt et al., 2017). Immature instars preferred ground waters with vegetation, and mostly in suburban or rural areas around cities. Females targeted amphibians and reptiles species (Kurucz et al., 2017; Camp et al., 2018).

Larvae of An. claviger were sampled at one locality in Mechroha during autumn season (October and November), which coincided with the overwintering period. Immature instars occurred in rural with dense vegetation and less profound breeding site. The population of this species overwintered from October to April as larvae. An. claviger was bivoltine (May and September) with fewer eggs in the second generation (Service, 1973).

Sixty-two immature mosquitoes of An. marteri species were collected from only one breeding locality in Taoura site in June. It is a permanent lake near a forest cover with altitude of $839 \mathrm{~m}$ which conferred favorable humidity. An. marteri was confined to the humid bioclimatic stage (Tabbabi et al., 2017). This zoophilic species was recorded in mountainous regions near the source of river at $812 \mathrm{~m}$ altitude (Bueno-Marí \& Jiménez-Peydró, 2010). It was found to breed mainly in permanent or temporary sunny current clear waters (Kassiri \& Amani, 2012).

Climate change and biodiversity has been correlated. Likewise, a climatic change affects habitats of several species which disrupts their adaptation ability, resulting in a significant loss in biodiversity. Recent study revealed that $C x$. quinquefasciatus abundance was associated with the environmental variables and suggested that these conditions during overwintering might be the key for West Nile virus amplification during summer outbreaks (Poh et al., 2019). Also, it was demonstrated that both immature and adult population dynamics of An. arabiensis was influenced by the climatic factors (Abiodun et al., 2016). Here, the link between climatic factors and mosquito diversity was evaluated over 12 months (December 2018 - November 2019). The abundance of mosquito's species was affected by the combination of temperature and rainfall which were negatively correlated. Globally, we found that mosquito abundances were greatest in just three months (from May to July) during which a gradual increase in temperature coincided with moderate precipitation, which significantly increased the humidity. Li et al. (2019) have shown that spatiotemporal vector dynamics could be predicted by climate conditions.

It has been reported also that temperature and rainfall were highly correlated with the mosquito abundance (Simon-Oke \& Olofintoye, 2015). Temperature influences ideal vector competence, viz. biting rate, parasite transmission and adult survivorship (Shapiro et al., 2017). However, immature mosquitoes were more sensitive than adults (Abiodun et al., 2016). So, increasing environmental temperature could decline the success of emergence and adult longevity, immature duration and survivorship (Christiansen-Jucht et al., 2014; Ukubuiwe et al., 2018).

On the other hand, climatic conditions governed natural vegetation dynamics (Al Balasmeh \& Karmaker, 2020) as suitable resting environments for adult mosquitoes from desiccating conditions with more available hosts which enhance their longevity (Arum et al., 2016). Also, warmer environmental temperatures lead to longer breeding seasons (Ryan et al., 2019). Throughout the present study period, the lowest larval abundances were observed during the coldest months. Unlike a moderate rainfall rate that could create new breeding sites through overflowing, excessive rainfall could eliminate habitats as already observed (Hamaidia K. et al., 2016). Temperature in the current week and rainfall 2-3 weeks before sampling had positive influences on mosquito abundance (Chuang et al., 2011).

Considering Shannon's diversity $\mathrm{H}^{\prime}$ index, Taoura and Sedrata were the most diversified geographic site in species $(\mathrm{S}=11)$, and Zarouria was the least one with the lowest species richness ( $\mathrm{S}=$ 3). Concerning Simpson's diversity D index, it showed that the diversity of these different sites was slightly variable between them. In general, the ecological indices revealed a medium diversity level of Culicidae fauna in Souk-Ahras province (global D $=0.50$, global $\mathrm{H}^{\prime}=1.79$ with $\mathrm{E}=0.42$ which means that the relative abundances of the species diverge away from evenness). 


\section{CONCLUSIONS}

Controlling immature mosquito instars can play a relevant contribution in vector control programs. In the scope of our survey, among 19 inventoried species, 6 are recorded for the first time in SoukAhras province which could pose a major concern. Recently, vector competence of Ur. unguiculata of a novel genetic lineage of West Nile virus (Kurucz et al., 2017; Camp et al., 2018) and Dirofilaria repens (Tippelt et al., 2017) was reported. Composition changes in mosquito population were revealed which could be due to climate change or/and inspection of more breeding sites Souk-Ahras. Lastly, assessment of further regular surveys is an urgent task to prepare and to respond better to potential risks of future likely vector borne diseases emergence.

\section{ACKNOWLEDGEMENTS}

This research was supported by the National Fund for Scientific Research of Algeria (Laboratory of Applied Animal Biology of Pr. N. Soltani) and by the Ministry of High Education and Scientific Research of Algeria (PRFU projects of Pr. N. Soltani).

\section{REFERENCES}

Abiodun G.J., Maharaj R., Witbooi P. \& Okosun K.O., 2016. Modelling the influence of temperature and rainfall on the population dynamics of Anopheles arabiensis. Malaria Journal, 15: 364. httpps://doi/ 10.1186/s12936-016-1411-6

Afrane Y.A., Githeko A.K. \& Yan G., 2012. The ecology of Anopheles mosquitoes under climate change: case studies from the effects of deforestation in East African highlands. Annals of the New York Academy of Sciences, 1249: 204-210.

Al Balasmeh O.I. \& Karmaker T., 2020. Effect of temperature and precipitation on the vegetation dynamics of high and moderate altitude natural forests in India. Journal of the Indian Society of Remote Sensing, 48: 121-144.

Amara Korba R., Alayat M.S., Bouiba L., Boudrissa A., Bouslama Z., Boukraa S., Francis F., Failloux A-B. \& Boubidi Saïd C., 2016. Ecological differentiation of members of the Culex pipiens complex, potential vectors of West Nile virus and Rift Valley fever virus in Algeria. Parasites \& Vectors, 9: 455. https://doi. org/10.1186/s13071-016-1725-9
Andreadis T.G., Armstrong P.M. \& Bajwa WI., 2010. Studies on hibernating populations of Culex pipiens from a West Nile virus endemic focus in New York City: parity rates and isolation of West Nile virus. Journal of the American Mosquito Control Association, 26: 257-264.

Arum S.O., Weldon C.W., Orindi B., Tigoi C., Musili F., Landmann T., Tchouassi D.P., Affognon H.D. \& Sang R., 2016. Plant resting site preferences and parity rates among the vectors of Rift Valley Fever in northeastern Kenya. Parasites \& Vectors, 9: 310. https:// doi.org/10.1186/s13071-016-1601-7

Asha A.V. \& Aneesh E.M., 2014. Diversity of mosquito species (Diptera: Culicidae) at Irinjalakuda, Thrissur with special reference to their breeding habitats. International Journal of Current Microbiology and Applied Sciences. 3: 536-541.

Asigau S. \& Parker P.G., 2018. The influence of ecological factors on mosquito abundance and occurrence in Galápagos. Journal of Vector Ecology, 43: 125137. httpps://doi/10.1111/jvec.12292

Bartlett-Healy K., Crans W. \& Gaugler R., 2008. Temporal and spatial synchrony of Culex territans (Diptera: Culicidae) with their Amphibian hosts. Journal of Medical Entomology, 45: 1031-1038.

Berenger J.-M. \& Parola P., 2017. Arthropod vectors of medical importance. In: Cohen J., Powderly W.G. \& Opal S.M. 2017. Infectious diseases. Elsevier, UK, 104-112.

Benallal K., Garni R., Bouiba L. \& Harrat Z., 2020. First detection of Aedes (Stegomyia) albopictus (Diptera: Culicidae) in Algiers, the capital city of Algeria. Iranian Journal of Arthropod-Borne Diseases, 13: 420425.

Benhissen S., Habbachi W., Masna F., Mecheri H., Ouakid M.L. \& Bairi A., 2014. Inventory Culicidae dry lands: The case of Oasis Ouled-Djellal (Biskra, Algeria). Revue El Wahat pour les recherches et les Etudes, 7: 86-91.

Benmalek L., Bendali-Saoudi F. \& Soltani S., 2018. Inventory and distribution of mosquitoes (Diptera; Culicidae) of the Burgas lakes (Northeast Algeria). Journal of Entomology and Zoology Studies, 6: 838-843.

Bingham A.M., Burkett-Cadena N.D., Porterfield C. \& Unnasch T.R., 2013. Innate preference or opportunism: mosquitoes feeding on birds of prey at the Southeastern Raptor Center. Journal of Vector Ecology, 39: 21-31.

Bogitsh B., Carter C. \& Oeltmann T.N., 2109. Human parasitology. Academic Press, UK, 422 pp.

Bouabida H., Djebbar F. \& Soltani N., 2012. Etude systématique et écologique des Moustiques (Diptera: Culicidae) dans la région de Tébessa (Algérie). Entomologie faunistique - Faunistic Entomology, 65: 99-103. 
Bouzidi O., Tine S., Hamaidia K., Tine-Djebbar F. \& Soltani N., 2020. Chemical composition and bioefficacy of essential oil from Bay Laurel Shrub (Laurales: Lauraceae) against Culiseta longiareolata (Macquart) (Diptera: Culicidae) larvae. Journal of Entomological Science, 55: 262-272.

Brown R., Hing C.T., Fornace K. \& Ferguson H.M., 2018. Evaluation of resting traps to examine the behaviour and ecology of mosquito vectors in an area of rapidly changing land use in Sabah, Malaysian Borneo. Parasites \& Vectors, 11: 346. https://doi. org/10.1186/s13071-018-2926-1

Brunhes J., Rhaim A., Geoffroy B., Angel G. \& Hervy JP., 1999. Les Culicidae d'Afrique méditerranéenne. Logiciel d'identification et d'enseignement, Montpellier, France, IRD \& ITP, CD-Rom collection didactique, IRD.

Bueno-Marí R. \& Jiménez-Peydró R., 2010. New anopheline records from the valencian autonomous region of Eastern Spain (Diptera: Culicidae: Anophelinae). European Mosquito Bulletin. 28: 148-156.

Camp J.V., Bakonyi T., Soltész Z., Zechmeister T. \& Nowotny N., 2018. Uranotaenia unguiculata Edwards, 1913 are attracted to sound, feed on amphibians, and are infected with multiple viruses. Parasites \& Vectors, 11: 456. https://doi.org/10.1186/s13071018-3030-2

Chaiphongpachara T., Yusuk P., Laojun S. \& Kunphichayadecha C., 2018. Environmental factors associated with mosquito vector larvae in a malaria-endemic area in Ratchaburi province, Thailand. The Scientific World Journal, 2018: 8. https:// doi.org/10.1155/2018/4519094

Christiansen-Jucht C., Parham P.E., Saddler A., Koella J.C., Basáñez M.-G., 2014. Temperature during larval development and adult maintenance influences the survival of Anopheles gambiae s.s. Parasites \& Vectors, 7: 489. https://doi.org/10. 1186/ s13071-014-0489-3

Chuang T.W., Hildreth M.B., Vanroekel D.L. \& Wimberly M.C., 2011. Weather and land cover influences on mosquito populations in Sioux Falls, South Dakota. Journal of Medical Entomology, 48: 669-679.

Djeghader N.E., Aissaoui L., Amira K. \& Boudjelida H., 2018. Toxicity evaluation and effects on the development of a plant extract, the Saponin, on the domestic mosquito, Culex pipiens. International Journal of Mosquitoes Research, 5: 1-5.

Dimentman C. \& Margalitj J., 1981. Rainpools as breeding and dispersal sites of mosquitoes and other aquatic insects in the Central Negev Desert. Journal of Arid Environment, 4: 123-129.

Dris D., Tine-Djebbar F., Bouabida H. \& Soltani N., 2017a. Chemical composition and activity of an $\mathrm{Oci}$ mum basilicum essential oil on Culex pipiens larvae:
Toxicological, biometrical and biochemical aspects. South African Journal of Botany, 113: 362-369.

Dris D., Tine-Djebbar F. \& Soltani N., 2017b. Lavandula dentata essential oils: Chemical composition and larvicidal activity against Culiseta longiareolata and Culex pipiens (Diptera: Culicidae). African Entomology, 25: 387-395.

Farjana T., Ahmmed M.S., Khanom T.F., Alam N. \& Begum N., 2015. Surveillance of mosquitoes larva at selected areas of Mymensingh district in Bangladesh. Bangladesh Journal of Veterinary Medicine, 13: 7988.

Foster W.A. \& Walker E.D., 2019. Mosquitoes (Culicidae). In: Mullen G.R. \& Durden L.A. 2019. Medical and veterinary entomology. Academic Press, Amsterdam, 261-325.

Fouque F. \& Reeder J.C., 2019. Impact of past and ongoing changes on climate and weather on vectorborne diseases transmission: a look at the evidence. Infectious Diseases of Poverty, 8: 51. https://doi.org/ 10.1186/s40249-019-0565-1

Godfray H.C., 2013. Mosquito ecology and control of malaria. Journal of Animal Ecology. 82: 15-25.

Guisande C., Heine J., García-Roselló E., González-Dacosta J., González-Vilas L. \& Pérez-Schofield B.J., 2017. DER: An algorithm for comparing species diversity between assemblages. Ecological Indicators, 81 : 41-46.

Hamaidia H. \& Berchi S., 2018. Etude systématique et écologique des Moustiques (Diptera: Culicidae) dans la région de Souk-Ahras (Algérie). Entomologie Faunistique - Faunistic Entomology, 71: 1-8.

Hamaidia K. \& Soltani N., 2014. Laboratory evaluation of a biorational insecticide, kinoprene, against Culex pipiens larvae: effects on growth and development. Annual Research and Review in Biology, 4: 2263 2273.

Hamaidia K., Tine-Djebbar F. \& Solatni N., 2016. Faune culicidiennes de la région de Souk-Ahras (Nord-Est Algérie) : Répartition spatiotemporelle et corrélation avec les facteurs du milieu. Editions Universitaires Européennes: Saarbrücken.

Hamaidia K. \& Soltani N., 2019. Compensation of kinoprene effect on reproduction of Culex pipiens by methoxyfenozide, an ecdysone agonist. Journal of Entomological Research, 43: 125-130.

Harrell F.E. Jr, with contributions from Charles Dupont and many others, 2020. Hmisc: Harrell miscellaneous. R package version 4.4-0. https://CRAN.Rproject.org $/$ package $=$ Hmisc

Hertig E., 2019. Distribution of Anopheles vectors and potential malaria transmission stability in Europe and the Mediterranean area under future climate change. Parasites \& Vectors, 12: 18. https://doi.org/ 10.1186/s13071-018-3278-6 
Hidalgo K., Siaussat D., Braman V., Dabiré K.R., Simard F., Mouline K. \& Renault D., 2016. Comparative physiological plasticity to desiccation in distinct populations of the malarial mosquito Anopheles coluzzii. Parasites \& Vectors, 9: 565. https://doi.org/ 10.1186/s13071-016-1854-1

Ihaka R. \& Gentleman R., 1996. R: a language for data analysis and graphics. Journal of Computational and Graphical Statistics. 5: 299-314.

Jones R., Kulkarni M.A., Davidson T.M.V., RADAMLAC Research Team \& Talbot B., 2020. Arbovirus vectors of epidemiological concern in the Americas: A scoping review of entomological studies on Zika, dengue and chikungunya virus vectors. PLoS ONE. 15: e0220753. https://doi.org/10.1371/journal.pone. 0220753

Karungu S., Atoni E., Ogalo J., Mwaliko C., Agwanda B., Yuan Z. \& Hu X., 2019. Mosquitoes of etiological concern in Kenya and possible control strategies. Insects, 10: 173. https://doi.org/10.3390/insects1006 0173

Kassambara A., 2019. ggcorrplot: Visualization of a Correlation Matrix using 'ggplot2'. R package version 0.1.3. https://CRAN.R-project.org/package $=$ ggcorrplot

Kassiri H. \& Amani H., 2012. Bionomics and breeding places of the genus Anopheles (Diptera: Culicidae) in Mahroo and Sepid-Dasht districts, Luristan province, Western Iran. Zahedan Journal of Research in Medical Sciences, 14: 11-17.

Kauffman E.B. \& Kramer L.D., 2017. Zika virus mosquito vectors: competence, biology, and vector control. Journal of infectious diseases, 216(suppl 10): S976-S990.

Khoobdel M., Keshavarzi D., Mossa-Kazemi S.H. \& Sobati H., 2019. Species diversity of mosquitoes of the Genus Culex (Diptera, Culicidae) in the coastal areas of the Persian Gulf. AIMS Public Health, 6: 99-106.

Kurucz K., Kemenesi G., Zana B., Zeghbib S., Oldal M. \& Jakab F., 2017. Ecological preferences of the putative West Nile virus vector Uranotaenia unguiculata mosquito with description of an original larval habitat North-Western. Journal of Zoology, 13: 193-199.

Lafri I., Bitam I., Beneldjouzi A. \& Ben Mahdi M.H., 2014. An inventory of mosquitoes (Diptera: Culicidae) in Algeria. Bulletin de la Société zoologique de France, 139: 255-261.

Lafri I., Prat C.M., Bitam I., Gravier P., Besbaci M., Zeroual F., Ben-Mahdi M.H., Davoust B. \& LeparcGoffart I., 2017. Seroprevalence of West Nile virus antibodies in equids in the northeast of Algeria and detection of virus circulation in 2014. Comparative Immunology Microbiology and Infectious Diseases, 50: $8-12$.

Lafri I., Hachid A. \& Bitam I., 2019. West Nile virus in
Algeria: a comprehensive overview. New Microbes and New Infections, 27: 9-13.

Li R., Xu L., Bjørnstad O.N., Liu K., Song T., Chen A., Xu B., Liu Q. \& Stenseth N.C., 2019. Climatedriven variation in mosquito density predicts the spatiotemporal dynamics of dengue. PNAS, 116: 3624-3629.

Lounaci Z., Doumandji S., Doumandji-Mitiche B. \& Berrouane F.Z., 2014. Dipterans biodiversity of agricultural and medico veterinary interest in the marsh of Reghaia (Algeria). International Journal of Zoology Research, 4: 71-82.

Lounaci Z., Doumandji S., Doumandji-Mitiche B. \& Taguemout M., 2016. Bioecology of Culicidae (Diptera ; Nematocera) of Taksebt dam of Tizi-Ouzou (Algeria). Advances in Environmental Biology, 10: 20-29.

Merabti B., Lebouz I., Adamou A.E., Kouidri M. \& Ouakid M.L., 2017. Effects of certain natural breeding site characteristics on the distribution of Culicidae (Diptera) mosquito species in Southeast Algeria. African Entomology, 25: 506-514.

Messai N., Berchi S., Boulknafd F. \& Louadi K., 2010. Inventaire systématique et diversité biologique de Culicidae (Diptera: Nematocera) dans la région de Mila (Algérie). Entomologie faunistique - Faunistic Entomology, 63: 203-206.

Messina J.P., Brady O.J., Golding N., Kraemer M.U.G., Wint G.R.W., Ray S.E., Pigott D.M., Shearer F.M., Johnson K., Earl L., Marczak L.B., Shirude S., Weaver N.D., Gilbert M., Velayudhan R., Jones P., Jaenisch T., Scott T.W., Reiner R.C.Jr. \& Hay S.I., 2019. The current and future global distribution and population at risk of dengue. Nature Microbiology, 4 : $1508-1515$.

Moon K-W., 2020. webr: Data and Functions for WebBasedAnalysis. R package version 0.1.5. https:// CRAN.R-project.org/package $=$ webr

Moradi-Asl E., Vatandoost H., Adham D., Emdadi D. \& Moosa-Kazemi H., 2019. Investigation on the Occurrence of Aedes Species in Borderline of Iran and Azerbaijan for control of arboviral diseases. Journal of Arthropod-Borne Diseases, 13: 191-197.

Pathak A.K., Shiau J.C., Thomas M.B. \& Murdock C.C., 2019. Field relevant variation in ambient temperature modifies density-dependent establishment of Plasmodium falciparum gametocytes in mosquitoes. Frontiers in Microbiology, 10: 2651. https://doi/10. 3389/fmicb.2019.02651

Pletterbauer F., Melcher A. \& Graf W., 2018. Climate change impacts in riverine ecosystems. In: Schmutz S. \& Sendzimir J. 2018. Riverine ecosystem management. Springer, Cham, 203-223.

Poh K.C., Chaves L.F., Reyna-Nava M., Roberts C.M., Fredregill C., Bueno Jr.R., Debboun M. \& Hamer 
G.L., 2019. The influence of weather and weather variability on mosquito abundance and infection with West Nile virus in Harris County, Texas, USA. Science of the Total Environment, 675: 260-272.

Prudhomme J., Fontaine A., Lacour G., Gantier J.C., Diancourt L., Velo E., Bino S., Reiter P. \& Mercier A., 2019. The native European Aedes geniculatus mosquito species can transmit chikungunya virus. Emerging Microbes \& Infections, 8: 962-972.

Reinhold J.M., Lazzari C.R. \& Lahondère C., 2018. Effects of the environmental temperature on Aedes aegypti and Aedes albopictus Mosquitoes: A Review. Insects, 9: 158, https://doi.org/10.3390/insects9040 158

R Core Team, 2019. R: A language and environment for statistical computing. R Foundation for Statistical Computing, Vienna, Austria. http://www.r-project. org/

Roiz D., Ruiz S., Soriguer R. \& Figuerola J., 2014. Climatic effects on mosquito abundance in Mediterranean wetlands. Parasites \& Vectors, 7: 333, https:// doi.org/10.1186/1756-3305-7-333

Ryan S.J., Carlson C.J., Mordecai E.A. \& Johnson L.R., 2019. Global expansion and redistribution of Aedesborne virus transmission risk with climate change. PLOS Neglected Tropical Diseases. 13: e0007213, https://doi.org/10.1371/journal.pntd.0007213

Saari S., Näreaho A. \& Nikander S., 2019. Canine Parasites and parasitic diseases. Academic Press, UK, 287 pp.

Service M.W., 1973. The biology of Anopheles claviger (Mg.) (Dipt., Culicidae) in southern England. Bulletin of Entomological Research. 63: 347-359.

Shapiro L.L.M., Whitehead S.A. \& Thomas M.B., 2017. Quantifying the effects of temperature on mosquito and parasite traits that determine the transmission potential of human malaria. PLoS Biology, 15: e2003489. https://doi.org/10.1371/journal.pbio.20 03489

Simon-Oke I.A. \& Olofintoye L.K., 2015. The Effect of Climatic Factors on the Distribution and Abundance of Mosquito Vectors in Ekiti State. Journal of Biology, Agriculture and Healthcare, 5: 142-146.

Simsek F., 2004. Seasonal larval and adult population dynamics and breeding habitat diversity of Culex theileri Theobald, 1903 (Diptera: Culicidae) in the Gölbaşi District, Ankara, Turkey. Turkish Journal of Zoology, 28: 337-344.

Sintayehu D.W., 2018. Impact of climate change on biodiversity and associated key ecosystem services in Africa: a systematic review. Ecosystem Health Sustainability, 4: 225-239.
Tabbabi A., Rhim A. \& Daaboub J., 2017. Mosquitoes (Diptera: Culicidae) in Tunisia, with particular attention to proven and potential vectors: A review. Journal of Tropical Diseases \& Public Health. 5: 1000249. https://doi.org/10.4172/2329-891X.1000 249

Tabbabi A., Laamari A., Cheikh R.B., Jha I.B., Daaboub J. \& Cheikh H.B., 2018. Resistance development and insecticide susceptibility in Culex pipiens pipiens, an important vector of human diseases, against selection pressure of temephos and its relationship to cross-resistance towards organophosphates and pyrethroids insecticides. African Health Sciences. 18: 1175-1181.

Tandina F., Doumbo O., Yaro A.S., Traoré S.F., Parola P. \& Robert V., 2018. Mosquitoes (Diptera: Culicidae) and mosquito-borne diseases in Mali, West Africa. Parasites \& Vectors, 11: 467. https://doi.org/10. 1186/s13071-018-3045-8

Tippelt L., Walther D. \& Kampen H., 2017. The thermophilic mosquito species Uranotaenia unguiculata Edwards, 1913 (Diptera: Culicidae) moves north in Germany. Parasitology Research, 116: 3437-3440.

Trájer A.J. \& Padisák J., 2019. Exploration of the main types of biome-scale culicid entomofauna (Diptera: Culicidae) in Europe and its relationship to the occurrence of mosquito-borne arboviruses. Acta Zoologica Academiae Scientiarum Hungaricae, 65: 299-322.

Ukubuiwe A.C., Olayemi I.K., Arimoro F.O., Omalu I.C.J., Baba B.M., Ukubuiwe C.C., Odeyemi M.O. \& Adeniyi K.A., 2018. Influence of rearing-water temperature on life stages' vector attributes, distribution and utilization of metabolic reserves in Culex quinquefasciatus (Diptera: Culicidae): implications for disease transmission and vector control. Journal of Basic and Applied Zoology, 79: 32. https:// doi.org/10.1186/s41936-018-0045-3

Walker K.R., Joy T.K., Ellers-Kirk C. \& Ramberg F.B., 2011. Human and environmental factors affecting Aedes aegypti distribution in an arid urban environment. Journal of the American Mosquito Control Association, 27: 135-141.

Waldock J., Chandra N.L., Lelieveld J., Proestos Y., Michael E., Christophides G. \& Parham PE., 2013. The role of environmental variables on Aedes albopictus biology and chikungunya epidemiology. Pathogens and Global Health, 107: 224-241.

Wickham H., 2016. ggplot2: Elegant graphics for data analysis. Springer-Verlag, New York, 260 pp.

Zimmerman R.H., 2019. The ecology of mosquito larvae (Diptera: Culicidae) in the subalpine zone of the eastern Sierra Nevada Mountains, California, U.S.A. Journal of Vector Ecology, 44: 154-172. 